\title{
The Role of Counsel in the Youth CRIminal Justice ACT
}

\author{
LARRY C. WILSON
}

The proper role of counsel in youth courl has always been some what uncertain. Historically, there was resistance to the idea of active participation by counsel. This began to change with the introduction of the Young Offenders Act. and the process continues with the Youth Criminal Justice Act. Counsel are under a legislated and ethical duty to take instructions from their clients and advocate on their behalf in the same fashion as with adult clients. However, the Youth Criminal Justice Act does not address two fundamental issues: 1) who pays for the provision of legal services; and 2) from whom does counsel receive instructions. These unanswered questions, and the complex nature of the legislation. further complicate the role of counsel in youth court.
Le bon röle du conseiller juridique dans le contexte des tribunaux pour la jeunesse a toujours éte quelque peu floue. Traditionnellement, il y a eu de la résistance à l'idèe de la participation active de la part d'un conseiller juridique. La situation a commencé à changer avec l'adoption de la Loi sur les jeunes contrevenants et le processus se maintient avec la Loi sur le système de justice pénale pour les adolescents. Les conseillers juridiques ont le devoir légal et éthique de suivre les instructions de leurs clients et de les représenter tout comme les clients adultes. Cependant, la Loi sur le système de justice pénale pour les adolescents ne tiem pas comple de deux questions fondamentales: I) qui doit payer pour la prestation des services juridiques et 2) de qui le conseiller doit-il stivre les instructions? Ces questions sans réponses et la nature complexe de la loi compliquent davantage le röle des conseillers juridiques des tribunaux pour les jeunes.

The proper role of counsel in youth court has always been somewhat uncertain. Historically, a major part of the problem was the fact that many of our judges were not adequately trained in law. In 1965 the Department of Justice Committee on Juvenile Delinquency noted that no professional conditions of qualification were required of persons appointed as juvenile court judges in Canada. Persons appointed to the position had backgrounds in the business world as well as in fields such as social work, divinity, psychology, and police work.'

From 1908 until 1982, the era of the Juvenile Delinquents $A c t,{ }^{2}$ the majority of children who appeared in juvenile court were not represented by counsel. It is not clear whether this was because parents were unaware of the right of the child to have counsel, could not afford to retain counsel, or simply felt they did not want or need counsel. ${ }^{3}$ In some instances the child was represented in court by a probation officer. Probation officers and police officers also acted as Crown counsel in some courts. This

Professor. Faculty of Law, University of Windsor.

Canada. Juvenile Delinquency in Canada: the Report of the Department of Justice Committee on Juvenile Delinquency (Ottawa: Queen's Printer, 1965) at 131 (hereinafter Juvenile Delinquency]. See also Ontario, Report of the Royal Commission Inquiry into Civil Rights, vol. 2 (Toronto: Queen's Printer, 1968) at 558 (Commissioner: J. McRuer).

= Juvenile Delinquents Act, R.S.C. 1970, c. J-3 [hereinafter JDA].

Juvenile Delinquency, supra note 1 at 143. 
was clearly unsatisfactory and the subject of criticism by both academics and members of the judiciary. ${ }^{4}$

Prior to the recent legislative initiatives there was considerable doubt as to whether or not lawyers could appear as of right in the juvenile court. ${ }^{5}$ This is particularly shocking when we consider that under the JDA somewhere between 95 to 99 percent of the children charged entered guilty pleas. ${ }^{6}$ Children often admitted the commission of delinquent acts which, when studied in retrospect by legally trained persons, indicated they should have entered not-guilty pleas and would have done so if they had obtained even a modicum of counsel from a lawyer. ${ }^{7}$ Gradually it became settled that, while there was a right to counsel, the presence of counsel was not in fact mandatory. ${ }^{8}$

When counsel did appear in the juvenile courts their presence was not always greeted with enthusiasm. Until the introduction of the Young Offenders $A c t^{9}$ in 1984, proceedings in juvenile court tended to be viewed as a matter of family law rather than criminal law. The courts were described as an informal inquisitorial system designed to rehabilitate and help misguided youth. ${ }^{10}$ This approach was promoted by the legislation itself. The $J D A^{\prime \prime}$ provided that a juvenile was not convicted or sentenced but was "adjudged" and "dealt with" and at all times was to be treated "not as criminal, but as a misdirected and misguided child, and one needing aid, encouragement, help and assistance."12

P.B. Chapman, "The Lawyer in Juvenile Court: A Gulliver among Lilliputians" (1971) 10 West. Ont. L. Rev. 88 at 91-92; Juvenile Delinquency, supra note I at 142; R. v. H. (1955), 20 C.R. 407 at 409 (B.C. S.C.).

D.E. Bowman, "Transfer Applications" in Isaac Pitblado on Continuing Legal Education, 1970: The Law and the Minor (Winnipeg: Manitoba Bar Association, 1970) 78 at 82. In "The Young Offender and the Courts" (1972) 6 R.F.L. 86 at 90. D.M. Steinberg argued that a child, not being sui juris, could not retain counsel. In Ex parte Grey (1958), 123 C.C.C. 70 at 71 (N.B. S.C. (A.D.)) the Court stated, "Counsel for the applicant took formal objection to the informant opposing the application and cited cases in which it was held that counsel for an informant has no status in criminal proceedings. Proceedings in a Juvenile Court are not criminal proceedings. The Crown is not, necessarily, a party to a proceeding in a Juvenile Court."

Chapman, supra note 4 at 90 .

W.T. Little, "A Guarantee of the Legal Rights of Children through Legal Aid" (1970) 4 Gazette 217 at 228

Re P, [1973] 2 O.R. 818 (H.C.J.): Bolton v. R. (1980), 25 B.C.L.R. 292 (S.C.). See J. Wilson. Children and the Law (Toronto: Butterworths, 1978) at 353; Ontario, Ministry of the Attorney General, "Report of the Committee on the Representation of Children in the Provincial Court (Family Division)" (1977) 29 R.F.L. 134; J. Leon, "Recent Developments in Legal Representation of Children: a Growing Concern with the Concept of Capacity" (1978) I Can. J. Fam. L. 375 at 417.

Young Offenders $A c t$, R.S.C. 1985, c. Y-1 [hereinafter YOA]. I. Dootjes, P. Erickson \& R.G. Fox, "Defence Counsel in Juvenile Court: A Variety of Roles" (1972) 14 Can. J. Crim. \& Corr. 132 at 133.

Supra note 2.

1. Ibid.. ss. 3(2), 38. It is important to note that despite the language of the legislation the Supreme Court of Canada did determine this to be valid federal legislation pursuant to the criminal law power in s. 91(27) of the Constitution Act, 1867 (U.K.), 30 \& 31 Vict., c. 3, reprinted in R.S.C. 1985, App. II, No. 5. See British Columbia (A.G.) v. Smith (1967), 65 D.L.R. (2d) 82 (S.C.C.). 
Accordingly, there was a considerable amount of resistance to active participation by defence counsel. It was suggested that it was not in the best interests of the child to have a delinquency charge dismissed as a result of quality representation by an astute attorney, as the child might be given a wrong impression and further delinquency could result. ${ }^{13}$ Defence counsel were often viewed as obstructionists, and the use of technical legal objections, in the case of a child apparently needing care, was frowned upon. Counsel was expected to act as the servant of the court in the process of ascertaining the child's needs to the point of actively encouraging a child to confess. An aggressive adversarial attitude was seen to harm the best interests of the young accused. ${ }^{14}$ Even after the enactment of the $Y O A$, some members of the judiciary continued to argue against the presence of counsel in youth court. ${ }^{\text {is }}$

The fears of those opposed to the presence of qualified counsel proved to be groundless. There was certainly no evidence to suggest that good lawyering was a root cause of delinquency. To the contrary, experience in Canada and other jurisdictions indicated profound results when lawyers became involved in the juvenile justice process. In 1982, a National Study on the Functioning of the Juvenile Court used court observation and court files to collect data on 2,000 juveniles accused of offences under the $J D A$. Courts in Montreal, Toronto, Winnipeg, Edmonton and Vancouver participated in the study. The research demonstrated that young people with legal representation entered fewer guilty pleas and had fewer convictions than those who appeared without counsel. ${ }^{16}$

In New York State, a number of studies demonstrated that increased appearances by lawyers reduced the incidence of temporary detention of children pending the court proceedings. The number of cases which were dismissed for failure of proof also rose dramatically. ${ }^{17}$ Court decisions across the United States on the right to counsel and procedure in the juvenile court caused a reduction in the volume of cases brought before the court or handled by its probation staff. ${ }^{18}$ These were positive developments and allowed authorities to concentrate their limited resources on proven and serious cases of criminality.

In response to the hostile environment found in some juvenile courts, Canadian lawyers began to create a variety of different, and in some cases, unfamiliar roles for themselves. The traditional advocate, amicus curiae and guardian were suggested as

1. H.D. Garrett. "Criminal Responsibility of Infants" (1966) 5 West. Ont. L. Rev. 97 at 99.

14 R.G. Fox, "The Young Offenders Bill: Destigmatizing Juvenile Delinquency?" (1972) 14 Crim. L.Q. 172 at 203.

15 In 1985, an Ontario Youth Court Judge, James Felstiner, suggested that the majority of young offenders did not need a lawyer and that when lawyers did appear they caused unnecessary delays. See K. Makin. "Use of Criminal Lawyers in Youth Courts Assailed" Globe \& Mail (5 November 1985) Al.

16. P. Carrington \& S. Moyer, "The Effect of Defence Counsel on Plea and Outcome in Juvenile Court" (1990) 32 Can. J. Crim. 621.

17 Chapman, supra note 4 at 107.

$18 \quad$ Fox, supra note 14 at 206. 
options. ${ }^{19}$ Most members of the defence bar were badly cast as "friendly interveners" or "wise judicious parents." In her research, Pamela Erickson found that the role of defence counsel was dictated, in large part, by the attitude of the juvenile court judge. Some of the judges interviewed by Erickson suggested that children did not need anyone to protect their rights since the juvenile court always acted in the child's best interests. Although many judges recognized the need for lawyers in juvenile court, they preferred that they limited themselves to advising on points of law and refrained from such tactics as vigorous cross-examination. ${ }^{20}$

Seventy years of experience with the $J D A$ clearly demonstrated the overwhelming advantages of the traditional adversarial model. The suggestion that a child's best interests demand any less representation or defence than would be expected in an adult court is entirely without substance. ${ }^{21}$ The lawyer's function as advocate is openly and necessarily partisan. Furthermore, counsel is required to raise every issue, advance every argument, ask every question which will help the client's case, and to endeavour to obtain for the client the benefit of every remedy and defence authorized by law. When defending an accused person, including a young offender, a lawyer's duty is to protect the client as far as possible from being convicted, except by a tribunal of competent jurisdiction and on legal evidence sufficient to support a conviction for the offence with which the client is charged. The lawyer should never abandon or waive the client's legal rights. ${ }^{22}$

Most commentators expected a dramatic change in the role of counsel as we moved from the parens patriae model of the $J D A$ to the "due process" approach of the $Y O A$. The new legislation made specific provision for the legal representation of alleged young offenders. Young people now had the clear legislated right to retain and instruct counsel without delay at any stage of the proceedings, including situations where there was consideration of whether or not to invoke "alternative measures," the new name for diversion programs. ${ }^{23}$ There was a generally held view that these new provisions

Leon, supra note 8. See also B. Dickens, "Legal Representation and Due Process in Delinquency Proceedings" (1978) 9 R.D.U.S. 20I; F. Maczko, "Some Problems with Acting for Children" (1979) 2 Can. J. Fam. L. 267.

211 P. Erickson, “The Defence Lawyer's Role in Juvenile Court: An Empirical Investigation Into Judges' and Social Workers' Points of View" (1974) 24 U.T.L.J. 126. See also P. Erickson, "Legalistic and Traditional Role Expectations for Defence Counsel in Juvenile Court" (1975) 17 Can. J. Crim. \& Corr. 78.

$\Rightarrow \quad$ Chapman, supra note 4 at 103.

$2 \quad$ Law Society of Upper Canada, Rules of Professional Conduct (Toronto: Law Society of Upper Canada, 2000) at r. 4, Commentary 58-59, online: Law Society of Upper Canada Homepage <www.Isuc.on.ca/services/RulesProfCondpage_en.jsp> (last modified: 12 July 2001). It is important to note that when engaged as a prosecutor, the lawyer's prime duty is not to seek to convict but to see that justice is done through a fair trial on the merits. See ibid. at Commentary 61 .

Supra note 9, s. 11(1). In R. v. Frohman; R. v. M.C.O. (1987), 60 O.R. (2d) 125 (C.A.), the Ontario Court of Appeal held that the police could conduct a preliminary screening with a roadside device without providing the opportunity to consult counsel. If a person failed the preliminary screening they could be asked to take a breathalyzer. The requirement that a young person be informed of his or her right to counsel was triggered when they failed a breathalyzer test. See $R$. v. S.M.M. (1988), 71 Sask. R. 229 (Q.B.); and R. v. M.J.L. (1986), 77 N.B.R. (2d) 212 (Q.B.) There are no changes in the Youth Criminal Justice Act which would suggest a different decision in future cases. 
and the "special guarantee" of the young person's rights imposed a higher duty on state authorities than that required by the Charter in respect of adults. ${ }^{24}$ Virtually identical "right to counsel" and "special guarantee" provisions have been included in the Youth Criminal Justice Act. ${ }^{25}$

Despite the fact that juvenile justice in Canada has taken on a much more "legalistic" overtone in recent years, some members of the profession continue to support the "guardian" role for defence counsel in youth court. Under this approach the "best interests of the child" are determined after consultation with probation officers, social workers, and parents. ${ }^{26}$ At the sentencing phase the "guardian" relaxes the traditional argument for the least restrictive measures and seeks a sentence which offers the best hope for rehabilitation. ${ }^{27}$ This approach assumes that effective rehabilitation programs are in place and available - an assumption that is overly optimistic at best. ${ }^{28}$ Furthermore, despite the work of many talented and dedicated individuals, there are, sadly, constant reminders of the fact that involvement in the youth criminal justice system can be very dangerous:

A 16-year-old hanged himself last month at a Toronto youth detention centre currently under attack for high levels of violence, grim physical conditions and slack supervision.... The young man - David Meffe - was the sixth young person to die in an Ontario-run institution since 1996... The five young people who have died since 1996 included one who was beaten to death, one who hanged himself, two who died while under restraint and one who died from complications involving his medication. ${ }^{29}$

P. Platt, Young Offenders Law in Canada, 2d ed. (Toronto: Butterworths, 1995) at 64. See ss. $3(1)(\mathrm{e})$ and $3(1)(\mathrm{g})$ of the YOA, supra note 9. In R. v. Edmond R.S. (in P. Platt, Young Offenders Service, looseleaf (Markham: Butterworths, 1984) at $11(1)(081)$ (hereinafter Young Offenders Service]), the Alberta Court of Appeal stated, "Parliament has inserted many words into the Young Offenders Act showing a presumption that a young offender particularly needs procedural protection, legal advice, and trial counsel." Youth Criminal Justice Act, S.C. 2002, c. 1, s. 25 [hereinafter $Y C J A$ ]. Section 3(1)(d)(i) provides that "young persons have special guarantees of their rights and freedoms."

H.A. Milne, R. Linden \& R. Kueneman, "Advocate or Guardian: The Role of Defence Counsel in Youth Justice" in R.R. Corrado et al., eds., Juvenile Justice in Canada: A Theoretical and Analytical Assessment, (Toronto: Butterworths, 1992) 313.

N. Bala, Youth Criminal Justice Law (Toronto: Irwin Law, 2003) at 338. This was an approach often suggested under the $J D A$ : "To be truly effective, the lawyer might assume his usually accepted role of advocate at the intake and adjudicatory stages, but not at the dispositional stage when he should assist the court in deciding what is best for rehabilitation of the juvenile." $K$. Wang, "The Continuing Turbulence Surrounding the Parens Patriae Concept in American Juvenile Court (Part l)" (1972) 18 McGill L.J. 219 at 226. and the Youth Justice System in Canada (Ottawa: The Task Force, 1996) at 197-394. See also "Recognizing the Limits of the Law" in Bala, ibid. at 572-74; and S. Anand, "Preventing Youth Crime: What Works, What Doesn't, and What It All Means for Canadian Juvenile Justice Policy" (1999) 25 Queen's L.J. 177.

:9 K. Makin, "Teen's suicide at centre for youths made public" Globe \& Mail (28 November 2002) A24. See also K. Makin, "Young offender centre called "hellish"' Globe \& Mail (27 November 2002) Al0; and V. Malarek, "Gangs Rule Youth Centre by Fear, Force, Guard Says" Globe \& Mail (29 November 2002) A27. 
Rather than vacillating between roles, the better view is that counsel must take instructions from his or her client and advocate on the client's behalf in the same fashion as he or she would do in respect of an adult client. ${ }^{30}$ Regardless of how lawyers view themselves, as strict or moderate advocates, or as strict or moderate guardians, their duty under the legislation and the canons of ethics of the profession is clear. ${ }^{31}$

This is not to suggest that counsel should ignore the personal characteristics and circumstances of the client, including age. ${ }^{32}$ Rather, counsel should continue to make important contributions at the intake, adjudication and disposition stages. When a young person is taken into custody it will be crucial to insure that the client understands his or her rights with regard to the taking of statements. ${ }^{33}$ In some situations counsel may be able to direct the young person to another, more appropriate agency, and with the consent of the Crown have charges withdrawn or dismissed. Defence counsel can advocate for extrajudicial sanctions (replacing the concept of "alternative measures") as provided by the new legislation. ${ }^{34}$ Where a court appearance is required, counsel can play an important role by interpreting the court and its procedure to both young persons and their parents. ${ }^{35}$ Aggressive and effective advocacy at both adjudication and disposition is also warranted. Given the fact that the vast majority of young people, as well as adults, will either plead guilty or be found guilty, extensive knowledge of suitable local and regional facilities is an absolute necessity. A well-formulated proposal for involvement in anger-management and substance-abuse programs is generally wellreceived by the courts. At the same time, a lawyer should be prepared to argue forcefully against any treatment strategy which could cause more harm than good. ${ }^{36}$

While the YCJA moves closer to the "junior Criminal Code" advocated by many and vehemently opposed by others, the new legislation does not resolve two fundamental problems that have plagued counsel under both the $J D A$ and the YOA - namely, who

31) Platt, supra note 24 at 308.

"Ibid. at 309. See also Report of the Subcommittee on Legal Representation of Children (Toronto: Law Society of Upper Canada, 1981).

32 Supra note 22 at r. 2.02(6): "When a client's ability to make decisions is impaired because of minority. mental disability, or for some other reason, the lawyer shall, as far as reasonably possible, maintain a normal lawyer and client relationship." Platt, supra note 24 at 64-66; and Bala, supra note 27 at 236-38. See also S. Scott. M. Wong \& B. Weagant, Defending Young Offenders Cases, 2d ed. (Scarborough: Carswell. 1997). Supra note 25, s. 10.

M. Peterson-Badali \& C.J. Koegl, "Young People's Knowledge of the Young Offenders Act and the Youth Justice System" (1998) 40 Can. J. Crim. 127 [hereinafter "Young People's Knowledge of the Young Offenders Act"]. See also M. Peterson-Badali \& R. Abramovitch, "Children's Knowledge of the Legal System: Are They Competent to Instruct Legal Counsel? (1992) 34 Can. J. Crim. 139.

3. According to Bala, supra note 27 at 346, "Sometimes the good intentions of these professionals outstrip their expertise, and intrusive sentencing plans are proposed that may be unrealistic or unlikely to help the youth. There is, for example, a tendency of some professionals to minimize the harmful effects of a custodial placement in terms of peer abuse and transmission of negative values from other young offenders, while over-emphasizing the rehabilitative potential of the programming available in custody." 
pays for the provision of legal services and from whom does counsel receive instruction?

For several years now, provincial governments across the country have sought ways to reduce expenditures under their legal aid programs. New restrictions in the eligibility criteria have become commonplace, and counsel argue they are overworked and underpaid. ${ }^{37}$ This frustration recently boiled over in the province of Ontario, where legal aid is delivered under a certificate system that allows clients to hire any lawyer willing to represent them under the province's legal aid fee schedule. ${ }^{38}$ That fee structure had remained virtually unchanged for 15 years. In a truly bizarre round of negotiations, lawyers rebelled and asked the courts to increase the fees in individual cases, with some success, and the province responded by threatening to scrap the certificate program and move to a system of public defenders. The matter was ultimately settled (at least for the time being), when lawyers voted to accept a 5 percent hike in the legal aid tariff. ${ }^{39}$

Much of the financial pressure placed on the provincial legal aid schemes has been attributed to the rising cost of defending young offenders. As noted earlier, in recognition of their special vulnerability the $Y C J A$ provides access to counsel beyond that provided to adults. If a young person appears in court without counsel, the judge will advise the youth of the right to counsel and give that person a reasonable opportunity to obtain counsel. ${ }^{40}$ If the young person is not able to obtain counsel he or she will be referred to a provincial legal aid program." If no legal aid program is available, or if the young person has been unable to obtain counsel through the program, the youth court may, and on the request of the young person shall, direct that the young person be represented by counsel. ${ }^{42}$ Where the youth court judge issues such direction the legislation provides that the Attorney General shall appoint counsel, or cause counsel to be appointed. ${ }^{43} \mathrm{An}$ adult may be denied legal aid on the basis that they fail to meet financial eligibility criteria or because their case is not considered to

"[L]egal aid programs in several provinces stagger through various stages of constriction.... According to most lawyers, it is just a matter of time before only the most inexperienced, desperate or ideologically committed lawyers will accept legal aid retainers" (K. Makin, "Lawyers waging battle in legal-aid trenches" Globe \& Mail (19 October 2002) Al1). See also "Legal aid hot topic at law conference" Lanyers Weekly (13 December 2002) 22.

This system is unique in Canada. While programs vary dramatically across the country (for example Newfoundland and Labrador and Saskatchewan use a public defender system), funding seems to be a universal problem. See "Nova Scotia lawyers considering boycott of legal aid work" Lanyers Weekly (13 December 2002) 3.

Makin, supra note 37 . Many lawyers in the province have continued to protest the new fees. In response, the Ontario government has forged ahead and passed legislation which would allow the introduction of public defenders. See "Ontario Legislature approves bill allowing public defenders" Lawyers Weekly (6 December 2002) 1. For a discussion of the Fisher applications (to increase hourly rates) and a comment on alternative delivery systems see "Ontario's Bar reacts angrily to plan for public defenders" Lawyers Weekly (II October 2002) at I: and "Bar handles only $2 \%$ of criminal cases in Newfoundland and Saskatchewan" Lawyers Weekly (11 October 2002) at 7.

Ibid., s. 25(4)(a).

Ibid., s. 25(4)(b).

lbid., s. 25(5). 
be sufficiently complex or serious. However, under the provisions of the $Y C J A$, a young person can receive legal aid for even the most minor criminal offence. ${ }^{44}$ While these provisions do not create a requirement for mandatory representation, there is a clear legislative preference for the provision of counsel. At the same time, a young person can refuse counsel if he or she so desires. ${ }^{45}$

Before the young person can request and receive a judicial direction for the provision of legal counsel, there must be a situation where the young person has been "unable" to obtain counsel, either privately or through a provincial legal aid program. In rare cases, a young person may have sufficient resources to fund their own defence, but more often than not they will turn to their parents. There has been considerable controversy over the financial obligation of parents in this situation. While many parents may feel a moral obligation to fund their child's defence, others do not. The issue under the YOA, which will continue under the $Y C J A$, is whether or not a young person can be denied counsel if an able but reluctant parent refuses to hire a lawyer or make repayment to legal aid.

Shortly after the $Y O A$ came into force there were several decisions which held that parents did not have a legal obligation to pay for their child, ${ }^{46}$ and in $R$. v. C.(S.T.); R. v. T.(D.M.), the Alberta Court of Queen's Bench ruled that the legislation did not require or even permit an inquiry into the young person's inability to obtain counsel. ${ }^{47}$ As money tightened, the provinces tried again and this time the courts were much more receptive. In $R$. v. M.(B.), a 1999 decision of the Ontario Court of Appeal, Finlayson J.A. expressed sympathy for the economic plight of the provinces: "It is the responsibility of those who administer the legal aid plan to see that its limited resources are husbanded for those most in need of representation and to ensure that the plan is not taken advantage of by accused persons who have directly or indirectly the resources to retain counsel privately." ${ }^{\prime 8}$ Accordingly, he held that a youth court judge had erred by failing to inquire into the parental resources available to a young person before making an order directing the appointment of counsel. The Court did acknowledge that, while there was an obligation to make such an inquiry, there was in fact no authority which would allow the courts to actually order parents to pay for the cost of a lawyer. ${ }^{49}$ Thus, if a youth court judge found that parents who had funds to pay for

It Bala, supra note 27 at 324.

4s "Although s. 11 of the Young Offenders Act provides for advising the young person of his right to counsel and for appointment of counsel, there is no authority, aside from the issue of insanity at time of trial, to force counsel upon a young person who does not wish to be represented" (R. v. H.E.A., Young Offenders Service, supra note 24 at 11(4)(025)). See also R. v. C.L.D.. Young Offenders Service, supra note 24 at $1 \mathrm{I}(4)(026)$.

R. v. Ronald H. (1984). 12 W.C.B. 334 (Alta. Prov. Ct.); R. v. M. (1985), 14 W.C.B. 344 (Ont. Prov. Ct.).

${ }^{47} \quad$ R. v. C.(S.T.); R. v. T.(D.M.) (1993), 81 C.C.C. (3d) 407 (Alta. Q.B.).

4* R. v. M.(B.) (1999), 28 C.R. (5th) 129 at 136 (Ont. C.A.).

4) $\quad$ Ibid. at 138 
counsel were unwilling to do so, the young person would be considered unable to obtain counsel and a direction for the appointment of counsel would be ordered. ${ }^{50}$

During these inquiries many parents undoubtedly felt pressured and embarrassed into contributing funds for the defence of their child. Lawyers were being put in the uncomfortable position of being asked by someone other than their client, namely the parents, to explain their rights and responsibilities. The federal government has attempted to end this confusing situation by responding to provincial concerns about the cost of legal aid through the enactment of s. 25(10) of the $Y C J A$. This new provision provides that the provinces can establish programs to recover the costs of a young person's counsel from the parents of the young person. ${ }^{51}$ All of the provinces will undoubtedly take advantage of this opportunity, and we can anticipate the usual crazy quilt of approaches from the different jurisdictions.

With this new clawback provision there will be a number of troubling scenarios. For example, there could be situations where parents will be expected to provide financial assistance when the young person no longer lives at home, is beyond their control, or even conceivably when they themselves are the victim of the offence. There is also a legitimate concern that parents, facing the prospect of large legal bills, will actively encourage their children to either admit offences of which they are innocent or enter guilty pleas. $^{52}$

While these repayment programs appear to be aimed primarily at middle-class families, some provincial governments in Canada are almost certain to try and include those on social assistance, particularly those low-income families who own their own homes. For example, in Ontario, persons on assistance who receive legal aid can be required to repay those costs and a lien can be placed on their home. ${ }^{53}$ There have been cases in that province where the parents of a young person have refused to accept a lien. ${ }^{54}$ With the addition of s. 25(10) we may very well see a situation where a

Bala described the decision as unfortunate, disappointing and contrary to both the spirit and words of the YOA. See N. Bala, "Trying to Make Parents Pay for Their Children's Lawyers" (1999) 28 C.R. (5th) 140. See also Bala, supra note 27 at 327-29; and P. Platt, supra note 24 at $311-14$. Supra note 25, s. 25(10).

52 Bala, supra note 27 at 330 . Bala also points out that while s. $25(10)$ stipulates that costs may be recovered only after the proceedings have been completed. parents could be required to reimburse the government regardless of whether or not the young person was convicted. See also FederalProvincial-Territorial Task Force on Youth Justice, supra note 28 at 501-28. In R. v. H.E.A., supra note 45 at para. 7, the Court stated, "I would find it difficult to be satisfied that a parent. for instance, has the required objectivity and expertise to properly advise the young person whether or not they should plead guilty. Parents may be guided by many motives, including the seeking of help for a troubled young person and encourage a totally inappropriate guilty plea."

"Applicants who own real estate are expected to use the property to finance legal fees privately. Only upon verification that private financing is not available, will legal aid offer assistance subject to a lien" (Legal Aid Ontario, A Guide to Legal Aid Ontario for Area Committee Members (September 2001) at 17).

"A legal aid program envisaged under subs. 11(4) of the Young Offenders Act must be a programme that makes counsel available to the young person without any overriding veto or consent power from another person (such as a parent who may or may not agree to a lien on family property in favour of the legal aid programme). The danger is that this other person may 
young person is refused legal aid because the parents will not accept a lien, counsel will be appointed because the young person is "unable" to obtain counsel, and then a lien will be placed upon the parental home under the provisions of a provincial repayment plan. Criminal activity by young people puts terrible stresses and strains on family relationships, and s. 25(10) can be expected to add to the problem.

Regardless of the financial involvement of parents, counsel will continue to struggle with establishing the proper relationship with the mother and father of their client. It should be noted that the picture often presented of a frightened and confused 13-yearold boy accompanied by his equally frightened and confused parents is somewhat misleading. A far more likely meeting will involve a 16- or 17-year-old accompanied by parents who have probably been through it all before. In any event, regardless of age, previous court experience and financial obligation, many - perhaps most parents see themselves as the client.

In $R$. v. W., a 1985 decision of the Manitoba Court of Appeal, Huband J.A. stated as follows:

In my view the appropriate practice is for the lawyer to receive instruction from the guardian, next friend, or guardian ad litem, in spite of the wording of s. 11 of the Young Offenders Act.... The instructions must come from the next friend or guardian, not the young offender directly.... Unless the court has cause to believe that the instructions are not in the interests of the young offender, it is the guardian's instructions which are to be followed by legal counsel for the infant. It would be unthinkable that the instruction of a responsible and caring father could be jettisoned at the instance of a twelve year old child who wished to pursue his own course. 55

Justice Matas disagreed:

In my view, we would be acting in accordance with the development of the common law and would be interpreting the Charter and the Act in accordance with the purposes of the enactments if we accept the principle that, if a young person is considered by Parliament to be capable of committing offences, the young person could also be capable of instructing counsel. ${ }^{56}$

The judgment of Huband J.A. was overtaken by an amendment to the $Y O A$, now found in s. 25(1) of the $Y C J A$, which provides that "a young person has the right to retain and instruct counsel without delay, and to exercise that right personally." ${ }^{57}$ If the right to retain and instruct counsel is in fact that of the young person, we should question the need to include what is now s. 25(8) of the $Y C J A$. That section provides that, where it appears to a youth court judge that the interests of the young person and the interests of the parent are in conflict, or that it would be in the best interests of the

very well not have the same interests as the youth" $(R$. v. M., Young Offenders Service, supra note 24 at $11(8)(001))$. See also R. v. B.L.A., Young Offenders Service, supra note 24 at $11(4)(007)$. where a young person was refused a legal aid certificate on the grounds that his parents owned a house and legal aid required a lien which his parents had refused.

37 Supra note 25, s. 25(I) [emphasis added]. See Platt, supra note 24 at 64. 
young person to be represented by his or her own counsel, the judge is to ensure that the young person is represented by counsel independent of the parent. ${ }^{58}$ In a prosecution against a young person counsel represents the young person, not the young person and his or her parents.

Lawyers should not discourage parental involvement and support for their client. At the same time the lines must be drawn and it must be made very clear to parents, at the earliest possible stage, that counsel is required to seek instructions from the client and to respect the confidential nature of that relationship. ${ }^{59}$ Obviously, some flexibility and consideration for the parent-child relationship is essential. Parents and guardians should be consulted and they should be constantly updated with the progress of the case. On the other hand, despite this uneasy balancing act, counsel must never lose sight of the primary ethical and legal obligation to the young person, their client, who is often at risk of incarceration.

The ability to actually receive meaningful instructions from a young client has often been questioned. ${ }^{60}$ These concerns also arise in the case of adult clients, many of whom are equally scared, confused, and unable to express themselves in a clear and focused manner. In the same way that police are expected to engage in age-appropriate discussions, lawyers are more than capable of doing the same with their clients. The ability to instruct counsel does not require a detailed knowledge of law and criminal procedure. Where a client can provide counsel with a recitation of facts, an indication of guilt or innocence, and appear able to participate in and understand in a general way the trial process that person should be considered competent. ${ }^{61}$ The FederalProvincial-Territorial Task Force on Youth Justice examined the available research and concluded that youths who are 12 years of age or older have a general competency to instruct counsel. ${ }^{62}$ In the rare instance where the young person lacks even the minimal ability to understand their circumstances, they should be considered unfit to stand trial. ${ }^{63}$

In addition to the concerns noted above, the role of counsel is further complicated by the increasingly complex nature of the legislation itself. The representation of young offenders has clearly become an area of specialization demanding a thorough knowledge of the special rights and responsibilities of young people accused of crimes. One need only examine the provisions in the $Y C J A$ dealing with issues such as police

YCJA, ibid., s. 25 (8).

Federal-Provincial-Territorial Task Force on Youth Justice. supra note 28 at 530-32.

See Maczko, supra note 19 at at 272-74; "Young People's Knowledge of the Young Offenders Act," supra note 23.

Bala, supra note 27 at 340, citing Boudreau v. Benaiah (1998), 37 O.R. (3d) 686 (Gen. Div.), notes that there are two major decisions that all clients are expected to make: whether to plead guilty and whether to testify. Bala suggests, at 341 , that "there should be a presumption that a youth who is twelve years or older has the capacity to instruct a lawyer."

Federal-Provincial-Territorial Task Force on Youth Justice. supra note 28 at 535.

See s. 141 of the YCJA, supra note 25 and the Criminal Code, R.S.C. 1985, c. C-46, s. 677.22. The legislation does present some difficulty in that unfitness must be "on account of mental disorder"; Criminal Code. s. 2. See $R$. v. Steele (1991), 4 C.R. (4th) 53 (Que. C.A.); and $R$. v. Taylor (1992), 17 C.R. (4th) 37 (Ont. C.A.). 
questioning and "presumptive" offences to confirm this reality ${ }^{64}$ This is not "kiddie court." Lawyers working in the youth criminal justice system must use their special skills and knowledge to advocate on behalf of their clients. While every client is unique, there is no legitimate basis to deviate from ethical obligations on the arbitrary basis of age. 